\title{
Temporal Variation in the Importance of a Dominant Consumer to Stream Nutrient Cycling
}

\author{
Natalie A. Griffiths ${ }^{1 *}$ and Walter R. Hill ${ }^{2}$
}

\begin{abstract}
${ }^{1}$ Climate Change Science Institute and Environmental Sciences Division, Oak Ridge National Laboratory, Oak Ridge, Tennessee 37831-6301, USA; ${ }^{2}$ Illinois Natural History Survey and Prairie Research Institute, University of Illinois, Champaign, Illinois 61821, USA
\end{abstract}

\begin{abstract}
Animal excretion can be a significant nutrient flux within ecosystems, where it supports primary production and facilitates microbial decomposition of organic matter. The effects of excretory products on nutrient cycling have been documented for various species and ecosystems, but temporal variation in these processes is poorly understood. We examined variation in excretion rates of a dominant grazing snail, Elimia clavaeformis, and its contribution to nutrient cycling, over the course of 14 months in a well-studied, low-nutrient stream (Walker Branch, east Tennessee, USA). Biomass-specific excretion rates of ammonium varied over twofold during the study, coinciding with seasonal changes in food availability (measured as gross primary production) and water temperature (multiple linear regression, $\left.R^{2}=0.57, P=0.053\right)$. The contribution of ammonium excretion to nutrient cycling varied with seasonal changes in both biological (that is, nutri-
\end{abstract}

ent uptake rate) and physical (that is, stream flow) variables. On average, ammonium excretion accounted for $58 \%$ of stream water ammonium concentrations, $26 \%$ of whole-stream nitrogen demand, and $66 \%$ of autotrophic nitrogen uptake. Phosphorus excretion by Elimia was contrastingly low throughout the year, supplying only $1 \%$ of total dissolved phosphorus concentrations. The high average $\mathrm{N}: \mathrm{P}$ ratio $(89: 1)$ of snail excretion likely exacerbated phosphorus limitation in Walker Branch. To fully characterize animal excretion rates and effects on ecosystem processes, multiple measurements through time are necessary, especially in ecosystems that experience strong seasonality.

Key words: consumer; snails; excretion; nutrient spiraling; nitrogen; phosphorus; ammonium; uptake rate; stream; temporal variation.

\section{INTRODUCTION}

Animals can affect carbon and nutrient cycling through direct (that is, excretion, egestion) and indirect (that is, grazing, soil compaction, bioturbation) pathways. Excretion, the release of soluble

Received 10 January 2014; accepted 11 May 2014; published online 19 June 2014

Author contributions NAG and WRH conceived and designed the study, performed the research, analyzed the data, and wrote the paper. *Corresponding author; e-mail: griffithsna@ornl.gov metabolic waste products, is important in ecosystems because nitrogenous and phosphorus compounds excreted by consumers are readily taken up by primary producers and heterotrophic microorganisms. Excretory products of animals contribute to nutrient cycling and productivity in freshwater (for example, Vanni 2002; McIntyre and others 2007), marine (for example, Uthicke 2001; Davy and others 2002; Brzezinski and others 2013), and terrestrial (for example, McNaughton and others 1997; Hilderbrand and others 1999; Seagle 2003) 
ecosystems. Understanding the factors controlling animal excretion across species, space, and time will better inform nutrient cycling at the ecosystem scale.

Nitrogen $(\mathrm{N})$ and phosphorus $(\mathrm{P})$ excretion rates vary widely across species (Vanni and others 2002; McIntyre and others 2008; McManamay and others 2011) due to differences in body composition and variation in the $\mathrm{N}$ and $\mathrm{P}$ of food sources (Elser and Urabe 1999). External factors such as temperature (Gardner and others 1981; Devine and Vanni 2002) and food availability and quality (James and others 2007; Wilson and Xenopoulos 2011; Moslemi and others 2012) can also influence excretion rates. Because these variables are temporally dynamic, rates of excretion and nutrient cycling are likely to vary over time; but few studies have examined temporal variability in excretion rates (but see Devine and Vanni 2002; Martin and others 2007; Christian and others 2008). If excretion rates vary temporally, measurements collected at one point in time may not be representative of the overall role of excretion, especially when scaling up to the ecosystem level.

The extent to which excreted nutrients support ecosystem nutrient demand varies from less than $1 \%$ (Benstead and others 2010; Wilson and Xenopoulos 2011) to over 100\% (Vanni 2002; Small and others 2011), and can be ecosystem or organism specific (Hall and others 2003; Small and others 2011; Wilson and Xenopoulos 2011). The importance of consumer excretion to ecosystem nutrient cycling can vary based on excretion rate (Gettel and others 2007; Small and others 2011), consumer biomass (Hall and others 2003), consumer community composition (McIntyre and others 2008), food availability (Moslemi and others 2012), hydrology (Benstead and others 2010), and ecosystem nutrient demand (Wilson and Xenopoulos 2011). Although the contribution of excretion to primary production or nutrient demand has been determined for numerous ecosystem and consumer combinations, few studies have investigated how temporal variation in these processes may alter the role of excretion in nutrient recycling.

We examined temporal variation in excretion rates of a grazing snail (Elimia clavaeformis) and estimated the importance of the snail's excretion to nutrient cycling in a well-studied stream. Snails are widespread and important consumers in streams and often dominate consumer biomass and production (for example, Hawkins and Furnish 1987; Richardson and others 1988; Brown 2001). We conducted this study in Walker Branch, a firstorder, low-nutrient stream draining a temperate deciduous forest in eastern Tennessee, USA. Elimia is the dominant primary consumer in Walker Branch and other streams in east Tennessee (Mulholland and others 1983; Hill and others 1995, 2010). In Walker Branch, this snail comprises 95\% of invertebrate biomass, achieves densities greater than 1,000 individuals $\mathrm{m}^{-2}$, and exerts severe grazing pressure on periphyton (Newbold and others 1983; Rosemond and others 1993). Primary production, temperature, and nutrient uptake vary temporally in Walker Branch (Mulholland and others 1985a; Mulholland and Hill 1997; Roberts and others 2007), so we predicted that snail excretion and its potential role supporting stream nutrient cycling would vary as well. We hypothesized that $\mathrm{N}$ and $\mathrm{P}$ excretion rates would be highest in spring when primary production and thus food availability is high (Roberts and others 2007), but that the contribution of snail excretion to wholestream nutrient uptake would be greatest in summer when primary production and nutrient demand is low (Mulholland and others 1985a; Mulholland and Hill 1997; Roberts and Mulholland 2007). Because Elimia occurs at high densities in oligotrophic streams, we predicted its excretion would be a major contribution to nutrient flux in Walker Branch.

\section{MethodS}

\section{Site Description}

The West Fork of Walker Branch is a first-order stream draining a 38.4-ha forested catchment in the U.S. Department of Energy's Oak Ridge Reservation $\left(35^{\circ} 58^{\prime} \mathrm{N}, 84^{\circ} 17^{\prime} \mathrm{W}\right)$. The streambed is composed of dolomitic bedrock, and accumulations of cobble, gravel, and fine and coarse terrestrially derived organic matter. Stream water is moderately alkaline (mean pH 8) and nutrient concentrations are low (mean dissolved inorganic nitrogen $=31 \mu \mathrm{g} \mathrm{N}^{-1}$, mean soluble reactive phosphorus $=3 \mu \mathrm{g} \mathrm{P}^{-1}$ ) (Lutz and others 2012) and limit primary production and decomposition (Elwood and others 1981; Rosemond and others 1993, 2000).

Forest leaf phenology strongly affects ecosystem processes in Walker Branch. Before leaf emergence in early April, light availability and algal production are high (Hill and others 2001). Streamside trees (primarily beech, chestnut oak, tulip poplar, and umbrella magnolia) shade the stream from midApril to mid-October, and primary production is constrained by low light levels during this time (Roberts and others 2007). From late October to late December, abscised leaves cover much of the 
streambed, and heterotrophic nutrient demand is high (Mulholland and others 1985a). Snails graze extensively on these leaves until the first major spate flushes the leaves from the stream.

\section{Excretion Rates}

We measured $\mathrm{N}$ and $\mathrm{P}$ excretion rates by Elimia on 11 dates over a period of 14 months. We measured excretion by snails grazing on biofilm growing on the three dominant substrates in Walker Branch (cobble, bedrock, and leaves) to scale area-specific excretion rates to the stream reach based on the proportional abundance of these substrate types. We used the biomass-specific rates $\left(\mu \mathrm{g} \mathrm{N}\right.$ or $\mathrm{P} \mathrm{g}^{-1}$ ashfree dry mass $[\mathrm{AFDM}] \mathrm{h}^{-1}$ ) to examine the drivers of snail excretion over time, and used the reach-scaled area-specific rates $\left(\mathrm{mg} \mathrm{N}\right.$ or $\mathrm{P} \mathrm{m}^{-2} \mathrm{~h}^{-1}$ ) to examine the contribution of snail excretion to stream nutrient cycling over time. The specific methodology for measuring excretion rates and scaling these rates to the stream reach are described below.

\section{Excretion Measurements}

Nitrogen (as ammonium) and phosphorus (as total dissolved phosphorus; TDP) excretion was measured on eleven dates, from February 2012 to April 2013. For each measurement, all snails within an $11-\mathrm{cm}$ diameter metal ring $\left(95 \mathrm{~cm}^{2}\right)$ placed on the stream bed (on bedrock, cobble, or leaves) were collected with forceps and dropped into a 50-ml plastic centrifuge tube filled with filtered (Whatman GF/F, 0.7- $\mu \mathrm{m}$ nominal pore-size) stream water. The number of snails collected for each measurement ranged from 8 to 67 , depending on snail density. Each tube was capped as soon as the last snail was collected $(<3 \mathrm{~min}$ after the first snail was collected) and submerged in the stream for $1.5 \mathrm{~h}$. Density and incubation time did not appear to elicit a stress response (such as oxygen depletion) that affected excretion rates as there was no significant relationship between biomass-specific ammonium excretion rate and the biomass of snails in the tubes $(R=-0.16, P=0.10, n=105)$.

Water temperature was measured during the $1.5 \mathrm{~h}$ incubation with a digital thermometer. Two to three tubes containing stream water but no snails served as negative controls on each sampling date. At the end of the incubation, $40 \mathrm{~mL}$ of water were removed from the tube with a syringe and filtered into an acid-washed polyethylene bottle, which was immediately placed on ice. The bottles were transferred to a $-20^{\circ} \mathrm{C}$ freezer within $2 \mathrm{~h}$. Ammonium concentrations were measured by phenate colorimetry (APHA 2005) and TDP concentrations were measured by molybdate-blue colorimetry, following persulfate digestion (APHA 2005), on an autoanalyzer (AA3, SEAL Analytical). The analytical detection limits for ammonium and TDP were $2.5 \mu \mathrm{g} \mathrm{l}^{-1}$. We will refer to total dissolved phosphorus excreted by snails as phosphorus for the remainder of the paper.

The live mass of snails in each tube was determined by weighing the snails in the laboratory or by measuring the width of individual snails with digital calipers. Widths were converted to live mass using a widthmass regression (live mass $(\mathrm{mg})=1.104 *$ width $\left.(\mathrm{mm})^{2.97} ; R^{2}=0.99, n=125\right)$. Mean snail live mass (g live mass snail ${ }^{-1}$ ) varied little over the study period (one-way ANOVA, $F_{10,94}=1.20, P=0.30$ ), as these snails are long-lived and slow-growing, and several cohorts are present in the stream at a given time. For excretion calculations, live mass was converted to ashfree dry mass (AFDM) of the snail (soft tissue and shell). Mean snail AFDM was $5.09 \%( \pm 0.20 \%$ SE $)$ of live mass and ranged from 4.00 to $5.72 \%$ seasonally (W.R. Hill, unpublished data). Snail soft tissue dry mass is $3.88 \%( \pm 0.21 \%$ SE) of live mass (W.R. Hill, unpublished data). The biomass-specific excretion rate was calculated as the mass of ammonium or phosphorus excreted over time divided by the total snail AFDM inside each tube. The area-specific excretion rate was calculated as the mass of nutrient excreted over time divided by the sampling area.

\section{Reach-Scaled Excretion Rates}

Excretion rates of snails collected from bedrock, cobble, and leaves were measured to scale up excretion rates to the stream based on the proportional abundance of these substrates. Excretion rates of snails grazing on bedrock were measured on all dates ( $n=4-9$ replicates per date), except in December 2012. Excretion measurements of snails grazing on cobble were carried out in September and November 2012, and February and March 2013 ( $n=4-7$ replicates per date), coinciding with measurements of whole-stream ammonium uptake (described below). Excretion by snails grazing on leaves was measured in November and December 2012 (only ammonium excretion in December 2012), when leaves covered most of the streambed ( $n=5$ replicates per date).

Snail density and live mass measured from monthly surveys were used in estimating excretion at the reach scale. These measurements were taken over a larger area and with a greater sample size than the density and biomass estimates from our individual excretion measurements, and thus 
provided a better estimate for density and biomass at the reach scale. Density was measured at 40 locations on bedrock and 40 locations on cobbles and snail live mass was measured at 10 locations on both bedrock and cobble substrata. Snail width was converted to live mass using the previously described width-mass regression and then to snail AFDM. The biomass-density of snails $\left(\mathrm{g} \mathrm{AFDM} \mathrm{m}^{-2}\right.$ ) was calculated by multiplying density by snail AFDM.

To calculate a reach-scaled excretion rate, biomass-specific excretion rates measured on bedrock, cobble, and leaves were multiplied by the proportion of streambed composed of each of these substrates. Substrate composition was estimated to be $71 \%$ cobble and $29 \%$ bedrock ( $n=25$ transects), except in November 2012, when leaf cover was estimated to be $77 \%$ ( $n=29$ transects), and bedrock and cobble were estimated to cover 7 and $16 \%$ of the streambed, respectively. To calculate a reach-scaled area-specific excretion rate $(\mathrm{mg} \mathrm{N}$ or $\mathrm{P} \mathrm{m}^{-2} \mathrm{~h}^{-1}$ ), biomass-specific excretion rates $(\mathrm{mg} \mathrm{N}$ or $\mathrm{P} \mathrm{g}^{-1} \mathrm{AFDM} \mathrm{h}^{-1}$ ) were multiplied by reachscaled biomass-density estimates of snails (g AFDM m ${ }^{-2}$ ) when available, or using biomassdensity estimated from the excretion assay (November and December 2012).

\section{Periphyton and Snail Stoichiometry}

We measured periphyton and snail stoichiometry to compare periphyton and snail $\mathrm{N}: \mathrm{P}$ to excretion $\mathrm{N}: \mathrm{P}$. Periphyton stoichiometry also was used to calculate autotrophic nutrient uptake (described below). Periphyton was collected monthly with a brush and syringe from eight bedrock locations. Equal aliquots of the collected periphyton were filtered through two pre-weighed filters (GF/F, 0.7$\mu \mathrm{m}$ nominal pore-size), which were dried $\left(60^{\circ} \mathrm{C}\right)$ and reweighed. One filter was analyzed for phosphorus. The filter was ashed $\left(500^{\circ} \mathrm{C}\right)$, and its phosphorus content was determined using $1 \mathrm{~N} \mathrm{HCl}$ extraction followed by molybdate-blue colorimetry analysis (APHA 2005). The second filter was analyzed for nitrogen using a CN analyzer (Costech ECS 4010 Elemental Combustion System). Due to an analyzer malfunction, $\mathrm{N}$ data from 7 sampling dates were lost. For these 7 dates, periphyton C:N was estimated from periphyton $\mathrm{C}: \mathrm{P}$ based on a significant linear relationship $\left(R^{2}=0.61, P=0.04\right)$ between C:N and C:P. Standard error for each C:N value was calculated from this linear regression. The periphyton C:N data estimated from the regression were only used in the calculation of autotrophic nitrogen uptake. Periphyton N:P was compared to snail $\mathrm{N}: \mathrm{P}$ (described below) on the dates when periphyton $\mathrm{N}$ was measured directly. Periphyton carbon was estimated from periphyton AFDM, assuming C was $42 \%$ of AFDM (W.R. Hill, unpublished data for Walker Branch).

Mean snail N:P was obtained from 29 samples (10 snails per sample) of Elimia collected bimonthly in Walker Branch from 2004 to 2008. The soft body was removed from the shell of individual snails, dried at $60^{\circ} \mathrm{C}$, and weighed. Half of the snails in each sample were analyzed for nitrogen content with a Europa Hydra isotope ratio mass spectrometer at the UC Davis Stable Isotope Laboratory. The other half were ashed at $500^{\circ} \mathrm{C}$ and analyzed for $\mathrm{P}$ content as described for periphyton.

\section{Stream Ecosystem Nutrient Cycling Metrics}

We examined the contribution of snail excretion to whole-stream nutrient cycling by comparing excretion rates to three ecosystem metrics: (1) whole-stream ammonium uptake measured using steady-state ammonium releases, (2) autotrophic nutrient uptake, calculated from gross primary production measurements and the $\mathrm{C}: \mathrm{N}$ and $\mathrm{C}: \mathrm{P}$ of periphyton, and (3) volumetric excretion and excretion turnover distance. We describe the methods for these three metrics below.

\section{Whole-Stream Ammonium Uptake}

Reach-scaled area-specific ammonium excretion rates by snails $\left(\mathrm{mg} \mathrm{N} \mathrm{m}^{-2} \mathrm{~h}^{-1}\right)$ were compared to whole-stream ammonium uptake rates $\left(\mathrm{mg} \mathrm{N} \mathrm{m}^{-2}\right.$ $\mathrm{h}^{-1}$ ) to estimate the extent that snails contributed to stream nutrient cycling. Ammonium uptake rates were measured over a $108-\mathrm{m}$ reach in Walker Branch using steady-state injections (Tank and others 2006). Injections were performed on four dates for which there were corresponding snail excretion measurements: September and November 2012, and February and March 2013. A solution containing ammonium $\left(\mathrm{NH}_{4} \mathrm{Cl}\right)$ and chloride $(\mathrm{NaCl})$ as a conservative tracer was dripped into the stream at a rate of $48 \mathrm{~mL} \min ^{-1}$ using a pump (Q3CKC pump head, Fluid Metering Inc.), and samples were collected at five locations downstream of the pump. The target concentration for ammonium at the most upstream location (a wellmixed area $18.3 \mathrm{~m}$ downstream of the pump) was $40 \mu \mathrm{g} \mathrm{N}^{-1}$, and actual steady-state concentrations for the four nutrient releases ranged from 22.5 to $56.3 \mu \mathrm{g} \mathrm{N} \mathrm{I}^{-1}$ at this location. Two replicate water samples were collected at each location along the 
108-m reach just before the nutrient release to determine background concentrations, and again after reaching steady state (that is, plateau), as determined by stable-specific conductivity measurements. Specific conductivity was measured at each location using a hand-held conductivity probe (YSI30 model, YSI Inc.). Water samples were filtered in the field into acid-washed polyethylene bottles, immediately placed on ice, and then frozen $\left(-20^{\circ} \mathrm{C}\right)$ in the laboratory until analysis for ammonium concentrations as described above.

Ammonium uptake length $\left(S_{\mathrm{w}} ; \mathrm{m}\right)$ was calculated as the inverse slope of the natural log of the background-corrected ammonium concentration to background-corrected specific conductivity versus distance downstream (Stream Solute Workshop 1990). Uptake velocity $\left(V_{\mathrm{f}} ; \mathrm{mm} \mathrm{s}^{-1}\right)$ was calculated as: $V_{\mathrm{f}}=Q / W * S_{\mathrm{W}}$, where $Q\left(\mathrm{l} \mathrm{s}^{-1}\right)$ is stream discharge and $w(\mathrm{~m})$ is mean stream width. Mean stream width was calculated from width measurements taken approximately every $2 \mathrm{~m}$ along the 108-m long nutrient release reach. Ammonium uptake rate $\left(U ; \mathrm{mg} \mathrm{N} \mathrm{m}^{-2} \mathrm{~h}^{-1}\right.$ ) was calculated as: $U=V_{\mathrm{f}}$ * [nut $\left.\mathrm{namb}_{\mathrm{am}}\right]$, where [nut $\left.\mathrm{amb}\right]$ is the mean background ammonium concentration $\left(\mu \mathrm{g} \mathrm{N}^{-1}\right)$.

\section{Autotrophic Nutrient Uptake}

Autotrophic uptake of $\mathrm{N}$ and $\mathrm{P}$ was calculated on each excretion date by converting whole-stream rates of gross primary production (GPP) (method described below) from $\mathrm{g} \mathrm{O}_{2} \mathrm{~m}^{-2} \mathrm{~d}^{-1}$ to $\mathrm{g} \mathrm{C} \mathrm{m}^{-2} \mathrm{~d}^{-}$

${ }^{1}$ assuming a photosynthetic quotient of 1.2 , and then to net primary production (NPP) assuming an autotrophic respiration fraction of 0.43 (estimated for Walker Branch in Hall and Beaulieu 2013). Rates of NPP then were divided by the molar C:N ratio of periphyton (range across dates: 10:1-23:1) to determine gross uptake of $\mathrm{N}$ by periphyton. Rates of P uptake were calculated similarly (range of molar C:P for periphyton: 284:1-1,000:1). These calculations assume that periphyton stoichiometry reflects both the nutrient demand and the ratio of nutrients assimilated by the periphyton community.

\section{Volumetric Excretion and Excretion Turnover Distance}

We estimated the contribution of snail excretion to stream water nutrient concentrations by calculating volumetric excretion $\left(E_{\mathrm{v}} ; \mu \mathrm{g}^{-1}\right)$ and excretion turnover distance $\left(S_{\mathrm{E}} ; \mathrm{m}\right)$ on each date (McIntyre and others 2008; Benstead and others 2010). Volumetric excretion estimates the contribution of the excreted nutrient to nutrient concentrations in flowing water, and was calculated as: $E_{\mathrm{V}}=\left(E_{\mathrm{A}} * A * T / V\right)$, where $E_{\mathrm{A}}$ is the areal excretion rate $\left(\mu \mathrm{g} \mathrm{N}\right.$ or $\left.\mathrm{P} \mathrm{m}^{-2} \mathrm{~h}^{-1}\right), A$ is reach area (reach length * mean width; $\mathrm{m}^{2}$ ), $T$ is travel time (stream reach/water velocity; $h$ ), and $V$ is reach volume (reach length * cross-sectional area; $\left.\mathrm{m}^{3}\right)$. Volumetric excretion values were compared to background stream water ammonium and TDP concentrations to determine the contribution of $E_{\mathrm{V}}$ to dissolved nutrients.

Excretion turnover distance is the spiraling length for snail-excreted nutrients relative to ambient nutrients for a given reach length, and is calculated as $S_{\mathrm{E}}=\left(\left[\right.\right.$ nut $\left.\left._{\mathrm{amb}}\right] /\left[E_{\mathrm{V}}\right]\right) * L$, where $\left[\right.$ nut $\left._{\mathrm{amb}}\right]$ is the ambient stream water nutrient concentration $\left(\mu \mathrm{g}^{-1}\right)$, and $L$ is the reach length $(\mathrm{m})$. Stream reach was fixed at $200 \mathrm{~m}$ to calculate $E_{\mathrm{V}}$ and $S_{\mathrm{E}}$ because longitudinal snail surveys showed that snail density does not vary much along this reach (Mulholland and Rosemond 1992; W.R. Hill, unpublished data). Mean stream width was determined from a previously published regression between stream discharge at the weir and width (Roberts and others 2007); water velocity was determined from a relationship between the travel time of the conservative tracer (measured as specific conductivity) from nutrient releases and stream discharge at the weir (velocity $=13.707 * Q_{\text {weir }}+49.386 ; \quad R^{2}=0.97$ ); and mean stream depth was calculated from a previously published relationship between discharge at the weir and depth (Roberts and others 2007).

\section{Ecosystem Measurements}

Gross primary production (GPP) and ecosystem respiration (ER) were measured using the onestation, open-water exchange method (Odum 1956). A sonde (600OMS model with an optical dissolved oxygen sensor, YSI Inc.) logged dissolved oxygen and stream water temperature every $15 \mathrm{~min}$. The sonde was located in the middle of the stream reach where snails were collected for excretion measurements. Rates of GPP and ER were calculated from the rate of change of dissolved oxygen over time after accounting for reaeration (see Roberts and others 2007 for detailed methods). Photosynthetically active radiation (PAR) also was measured every 15 min with a PAR sensor (model S-LIA-M003, Onset Computer Corporation) that was elevated $\sim 50 \mathrm{~cm}$ above the water at a location $10 \mathrm{~m}$ upstream of the sonde.

Water chemistry samples were collected weekly approximately $40 \mathrm{~m}$ downstream of the snail excretion measurements to determine ambient nutrient concentrations. Details on water chemistry collection and analysis methods can be found in Lutz 
and others (2012). Stream discharge was measured at 15-min intervals at a V-notch weir $100 \mathrm{~m}$ downstream of the snail excretion measurements. Water chemistry and discharge data for Walker Branch are published at http://walkerbranch.ornl.gov.

\section{Statistical Analyses and Error Propagation}

We used multiple linear regression to examine the environmental factors influencing biomass-specific ammonium and phosphorus excretion rates. Two independent variables were chosen: GPP (an indicator of food quantity) and temperature (a potential driver of snail metabolism). We did not include a measure of periphyton quality (periphyton $\mathrm{N}: \mathrm{P}$ ) because of missing periphyton $\mathrm{N}$ data on multiple dates (described above).

Pearson's correlation was used to examine the relationships between stoichiometric measures and between excretion rates and ecosystem metrics. Correlation analysis was used to parse out the variation in $E_{\mathrm{V}}$ attributed to stream discharge versus excretion rate, even though we realize that these factors are inherently correlated, because discharge and excretion rate are both used to calculate $E_{\mathrm{V}}$. However, we used correlation analysis to determine which variable was contributing more to the temporal variation in $E_{\mathrm{V}}$. We also calculated coefficients of variation (CV) for each metric contributing to the calculation of $E_{\mathrm{V}}$. All statistical analyses were done using SYSTAT v.13.

Propagated standard errors were calculated for reach-scaled excretion rates and ecosystem nutrient cycling metrics (that is, whole-stream uptake, autotrophic uptake, and volumetric excretion $\left[E_{\mathrm{V}}\right]$ ) that were derived from multiple parameters.

\section{RESUlts}

\section{Physical and Chemical Variables and Snail Density and Biomass}

Stream discharge was high during the winter months (maximum Q: $161 \mathrm{l} \mathrm{s}^{-1}$ ) and was low and stable during the summer months (minimum $Q$ : $5 \mathrm{l} \mathrm{s}^{-1}$ ) (Figure 1A). Stream temperature followed a seasonal pattern of warm temperature in the summer (maximum: $16.6^{\circ} \mathrm{C}$ ) and cooler in the winter (minimum: $9.2^{\circ} \mathrm{C}$ ) (Figure $1 \mathrm{~B}$ ). PAR was strongly influenced by forest phenology, and was highest in spring before leaf out and lowest in summer when the canopy was full (Figure 1B). Stream water concentrations of ammonium and total dissolved phosphorus (the solutes measured as snail excretion products) were variable through time, with no clear temporal pattern. Ammonium concentrations averaged $4.4 \mu \mathrm{g} \mathrm{N} \mathrm{I}^{-1}$ and TDP concentrations averaged $6.4 \mu \mathrm{g} \mathrm{P} \mathrm{l}^{-1}$.

Snail density was relatively high in Walker Branch (mean reach-scaled density across dates: 2,103 individuals $\mathrm{m}^{-2}$ ) and reach-scaled density estimates ranged from 1,437 to 2,575 individuals $\mathrm{m}^{-2}$ (Figure 1C). Snail density was higher on bedrock than on cobble, and density on bedrock tended to be highest in summer when stream discharge was low. Snail density on bedrock decreased in late autumn when snails congregated on the leaves. Temporal variation in snail biomass mirrored the temporal pattern in snail density, and reach-scaled biomass averaged $4.1 \mathrm{~g} \mathrm{AFDM} \mathrm{m}^{-2}$, and ranged from 2.8 to $5.5 \mathrm{~g} \mathrm{AFDM} \mathrm{m}^{-2}$.

\section{Temporal Variation in Excretion Rates}

Ammonium excretion rates varied over twofold during the 14-month period of measurements (Figure 2). Biomass-specific ammonium excretion rates tended to be similar on bedrock, cobble, and leaves (Figure 2A). Temporal variation in biomassspecific excretion rates on bedrock was related to changes in both gross primary production and water temperature (Table 1; Figure 3; multiple linear regression, $\left.R^{2}=0.57, P=0.053\right)$. This relationship was stronger when excretion was expressed per live mass $\left(R^{2}=0.70, P=0.02\right)$ because snail AFDM changed seasonally, and was lower in summer when food availability was low. Gross primary production and temperature had similar effects on ammonium excretion expressed per AFDM based on similar standardized coefficients for GPP (0.62) and temperature (0.61) (Table 1).

Biomass-specific phosphorus excretion rates varied over time, with no apparent temporal pattern (Figure 4). There was high variability in the rate of phosphorus excretion on a given sampling day, and phosphorus excretion was essentially zero on several dates because measured phosphorus concentrations were similar in snail versus control tubes. Measured TDP concentrations in the control tubes were above the analytical detection limit $\left(2.5 \mu \mathrm{g} \mathrm{l}^{-1}\right)$ on every date except February 2012. There were no differences in biomass-specific phosphorus excretion rates of snails among bedrock, cobble, or leaf substrates (Figure 4A). There was no relationship between biomass-specific phosphorus excretion rate on bedrock and GPP and water temperature (Table $1 ; R^{2}=0.16, P=0.54$ ). There was no significant correlation between 


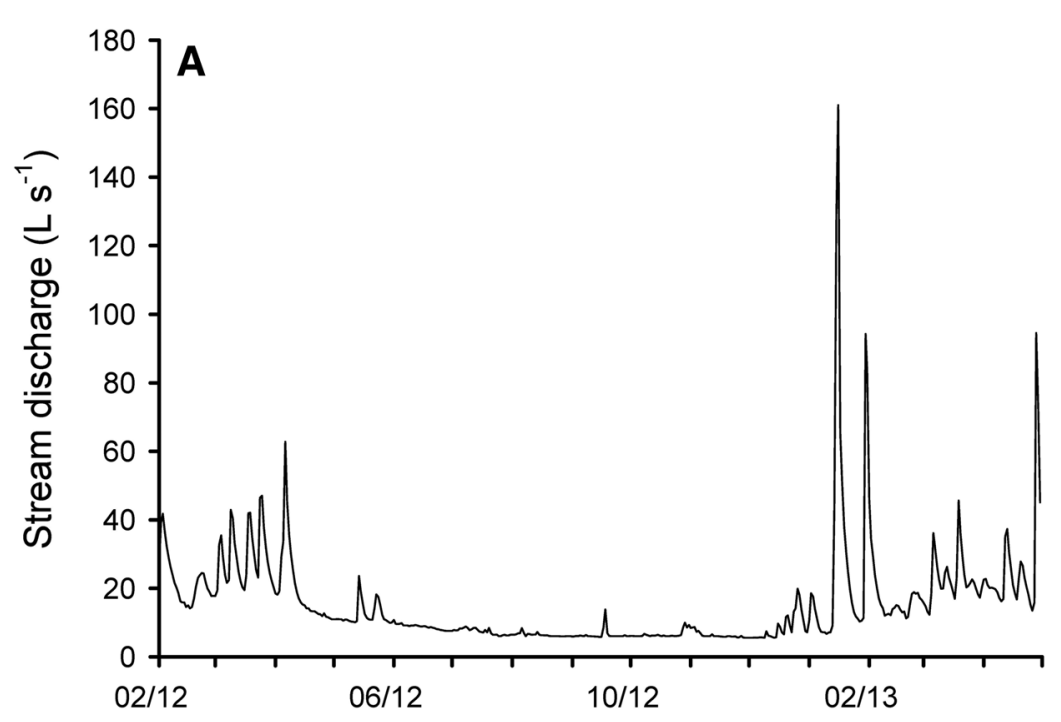

Figure 1. A Mean daily stream discharge, $\mathbf{B}$ mean daily stream water temperature and daily photosynthetically active radiation (PAR), and $\mathbf{C}$ snail density ( \pm standard error, SE) on bedrock (black circles), cobble (white circles), and leaves (gray circles), and reachscaled density (black-dotted line) in Walker Branch from February 2012 to April 2013.
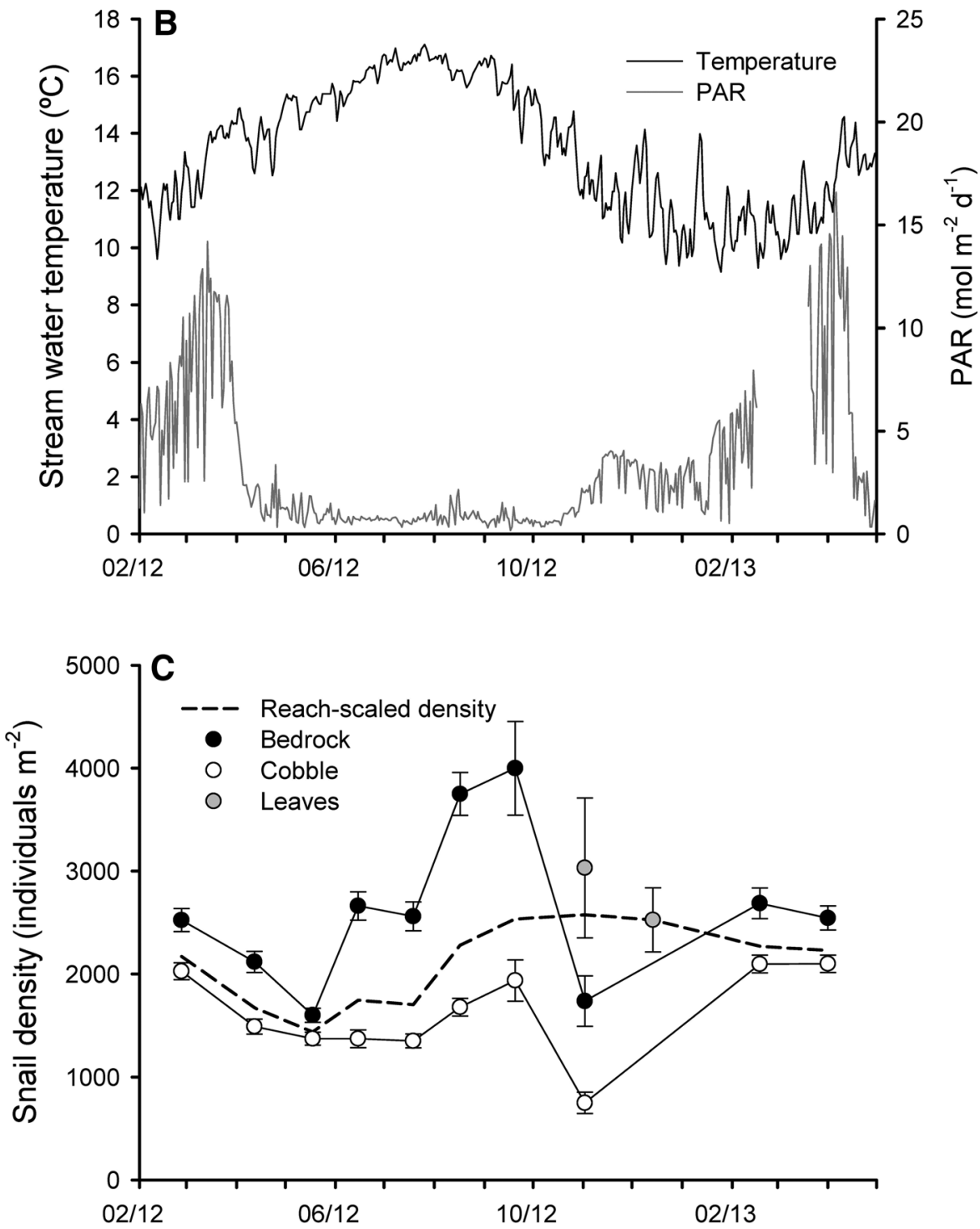

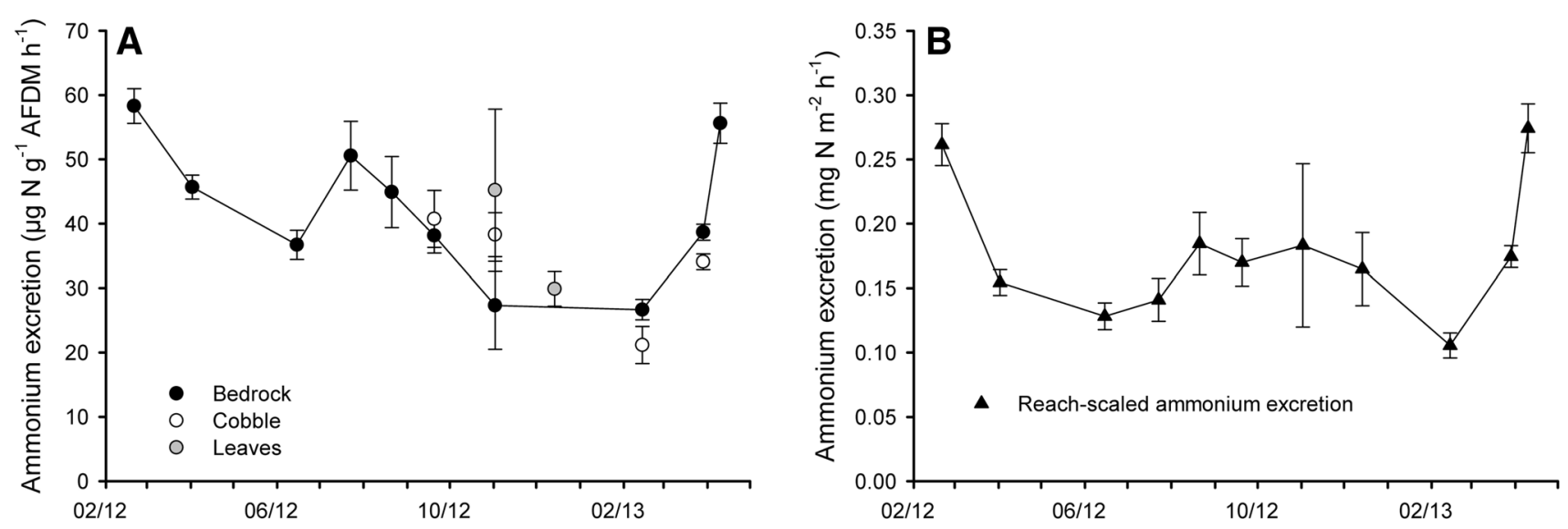

Figure 2. A Biomass-specific excretion of ammonium ( $\pm \mathrm{SE}$ ) by snails on bedrock (black circles), cobble (white circles), and leaves (gray circles), and B reach-scaled area-specific ammonium excretion (black triangles) ( \pm SE) measured approximately monthly or bimonthly in Walker Branch.

Table 1. Multiple Linear Regression Results Where Biomass-Specific Ammonium or Phosphorus Excretion Rate on Bedrock was the Dependent Variable, and Gross Primary Production (GPP) and Stream Water Temperature were the Independent Variables

\begin{tabular}{lllllllll}
\hline $\begin{array}{l}\text { Dependent } \\
\text { variable }\end{array}$ & $\begin{array}{l}\text { Independent } \\
\text { variables }\end{array}$ & Coefficient & Standard error & $\begin{array}{l}\text { Standardized } \\
\text { coefficient }\end{array}$ & $t$ & $P$ & Regression $R^{2}$ & Regression $P$ \\
\hline N excretion & GPP & 11.11 & 4.62 & 0.62 & 2.40 & 0.05 & 0.57 & 0.053 \\
& Temperature & 2.33 & 1.00 & 0.61 & 2.33 & 0.05 & & \\
P excretion & GPP & 0.84 & 0.72 & 0.41 & 1.16 & 0.28 & 0.16 & 0.54 \\
& Temperature & 0.06 & 0.16 & 0.13 & 0.37 & 0.72 & & \\
\hline
\end{tabular}

biomass-specific ammonium and biomass-specific phosphorus excretion rates on bedrock $(R=0.43$, $P=0.22)$.

\section{Contribution of Excretion to Ecosystem Nutrient Cycling}

\section{Nutrient Uptake}

Reach-scaled area-specific ammonium excretion rates accounted for $12-55 \%$ of whole-stream ammonium uptake rates $(U)$, and the contribution of snail excretion to whole-stream uptake was highest in September (prior to leaf fall), when $U$ was lowest (Figure 5). Ammonium uptake ranged from $0.31 \mathrm{mg} \mathrm{N} \mathrm{m}^{-2} \mathrm{~h}^{-1}$ in September 2012 to $1.08 \mathrm{mg} \mathrm{N} \mathrm{m}^{-2} \mathrm{~h}^{-1}$ in March 2013, and was higher when background ammonium concentration was higher.

Autotrophic nitrogen uptake estimated from GPP and periphyton $\mathrm{C}: \mathrm{N}$ ranged from $0.10 \mathrm{mg} \mathrm{N} \mathrm{m}^{-2}$ $\mathrm{h}^{-1}$ in November 2012 to $1.07 \mathrm{mg} \mathrm{N} \mathrm{m}^{-2} \mathrm{~h}^{-1}$ in April 2013. Reach-scaled ammonium excretion accounted for an average of $66 \%$ of autotrophic nitrogen uptake (range 16-189\%; Figure 6A). When GPP was low in August to November 2012, excretion accounted for more than $100 \%$ of autotrophic uptake.

Excretion of phosphorus by snails did not contribute as much as ammonium to uptake. Autotrophic phosphorus uptake rates varied from $0.01 \mathrm{mg} \mathrm{P} \mathrm{m}^{-2} \mathrm{~h}^{-1}$ in November 2012 to $0.05 \mathrm{mg} \mathrm{P} \mathrm{m}^{-2} \mathrm{~h}^{-1}$ in April 2013, and phosphorus excretion accounted for $0-46 \%$ of autotrophic phosphorus uptake (Figure 6B).

\section{Volumetric Excretion and Excretion Turnover Distance}

Snail excretion contributed $1.5-5.2 \mu \mathrm{g} \mathrm{N}^{-1}\left(E_{\mathrm{V}}\right)$ to total stream water ammonium concentrations, which ranged from 2.5 to $11.0 \mu \mathrm{g} \mathrm{N}^{-1}$ during the excretion measurements (Figure 7A). On average, $58 \%$ of stream water ammonium was derived from snail excretion. Both physical (that is, stream discharge) and biological (that is, excretion rate) variables are used to calculate volumetric excretion, and temporal variability in $E_{\mathrm{V}}(\mathrm{CV}=0.41)$ was due primarily to variable stream discharge $(\mathrm{CV}=0.52, R=-0.64, P=0.03)$ rather than to variable excretion rates $(\mathrm{CV}=0.29, R=0.11$, $P=0.75)$. The contribution of snail excretion to stream water ammonium concentrations was 


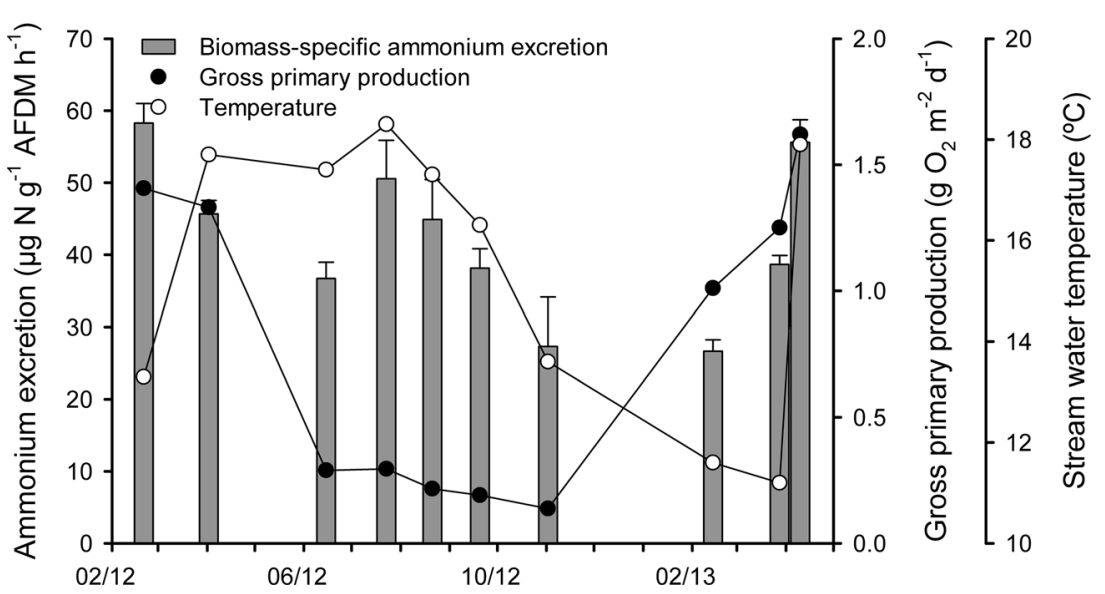

Figure 3. Temporal variation in biomassspecific ammonium excretion on bedrock (gray bars; +SE), gross primary production (GPP) (black circles), and mean stream water temperature (white circles) to illustrate the drivers of ammonium excretion rates.
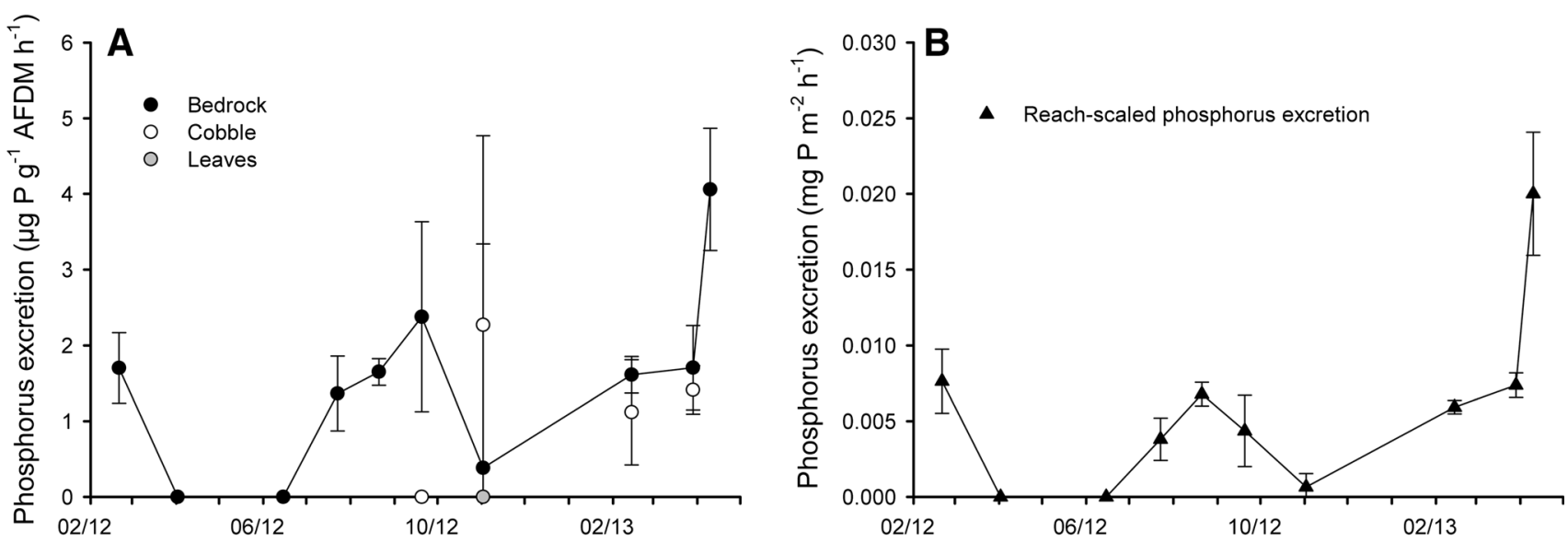

Figure 4. A Biomass-specific excretion of phosphorus ( $\pm \mathrm{SE}$ ) by snails on bedrock (black circles), cobble (white circles), and leaves (gray circles), and B reach-scaled area-specific phosphorus excretion (black triangles) $( \pm \mathrm{SE})$ measured approximately monthly or bimonthly in Walker Branch.

highest in summer during low-flow periods. There was no correlation between ammonium $E_{\mathrm{V}}$ and temperature $(R=0.29, P=0.38)$, and there was no correlation between the percentage of stream water ammonium derived from snail excretion and the percentage of snail excretion contributing to whole-stream ammonium uptake $(R=0.15$, $P=0.84)$.

The contribution of snails to total dissolved phosphorus concentration via excretion $\left(E_{\mathrm{V}}\right)$ was much lower than that of ammonium, and ranged from 0 to $0.2 \mu \mathrm{g} \mathrm{P} \mathrm{l}^{-1}$. Total dissolved phosphorus concentrations in stream water ranged from 4.0 to $10.1 \mu \mathrm{g} \mathrm{P} \mathrm{l}^{-1}$ during the excretion measurements, and excretion contributed 0 to $4.5 \%$ to these concentrations (mean 1.4\%) (Figure 7B). Temporal variation in phosphorus $E_{\mathrm{V}}(\mathrm{CV}=0.89)$ was primarily due to differences in excretion rates $(\mathrm{CV}=1.04, R=0.85, P=0.002)$ rather than dis- charge $(\mathrm{CV}=0.52, \quad R=-0.12, \quad P=0.74)$. There was no correlation between phosphorus $E_{\mathrm{V}}$ and temperature $(R=0.19, P=0.59)$.

Turnover distances $\left(S_{\mathrm{E}}\right.$; spiraling length for snailexcreted nutrients relative to ambient nutrients for a given reach length) were an order of magnitude shorter for ammonium (range 134-894 m; mean: $446 \mathrm{~m}$ ) than for phosphorus (range 4,422$99,529 \mathrm{~m}$; mean: $23,145 \mathrm{~m}$ ) due to the much greater rate of snail-derived ammonium versus phosphorus excretion. $S_{\mathrm{E}}$ for ammonium was longer than uptake lengths $\left(S_{\mathrm{w}}\right)$ determined from steady-state ammonium additions (range 26$123 \mathrm{~m})$.

\section{Stoichiometry}

The mean molar ratio of ammonium to phosphorus excretion by Elimia (89:1) was much higher than 


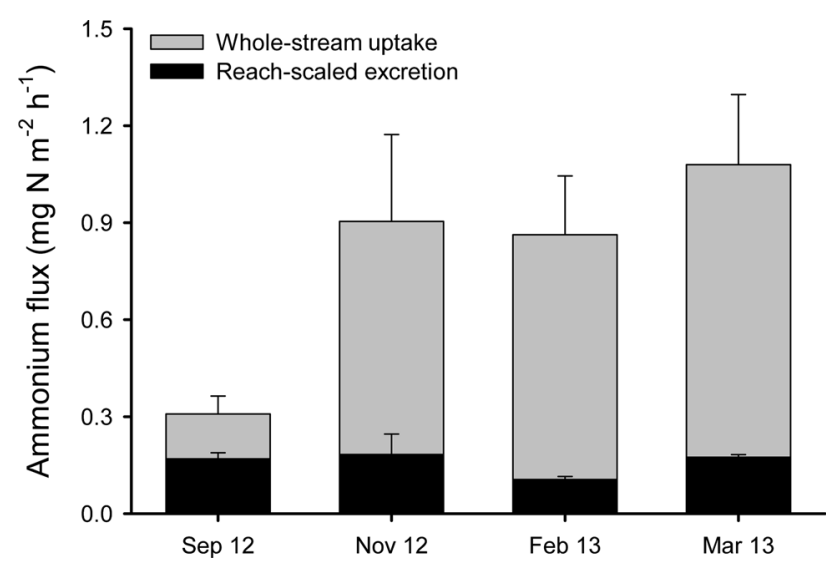

Figure 5. Whole-stream areal uptake rates of ammonium (gray bars) overlaid with reachscaled area-specific excretion rates of ammonium by snails (black bars) measured on 1 day in September and November 2012, and February and March 2013. Error bars represent propagated standard errors.
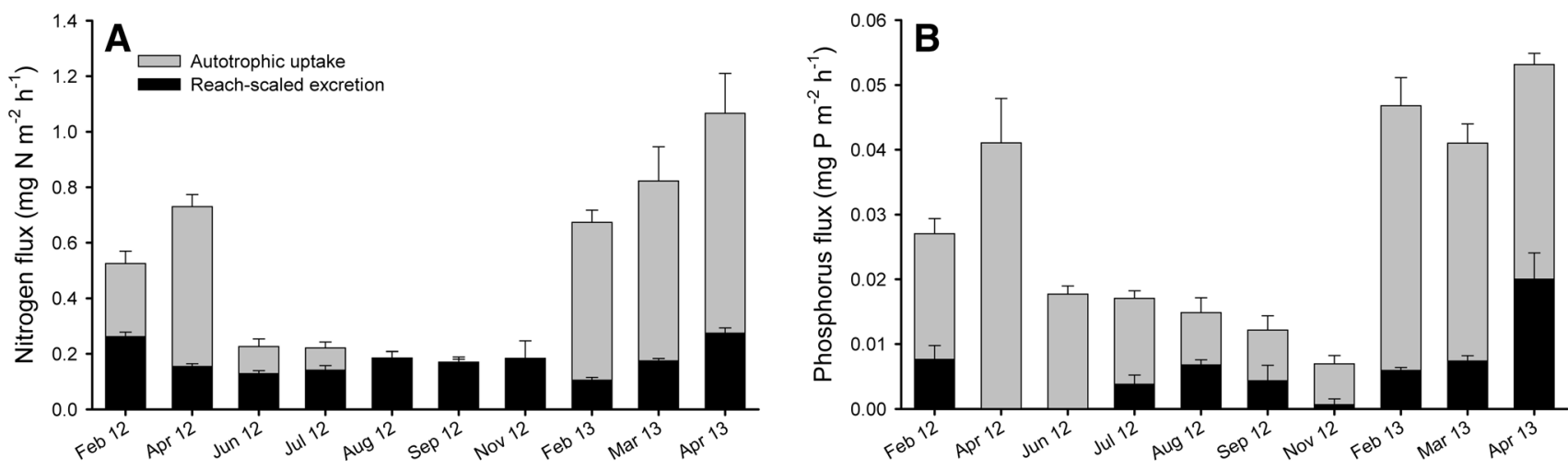

Figure 6. A Uptake of nitrogen and B phosphorus by autotrophs (gray bars) overlaid with reach-scaled area-specific excretion rates of ammonium and phosphorus (black bars), respectively, from February 2012 to April 2013. Error bars represent propagated standard errors.

that of Elimia soft tissue (26:1), periphyton (38:1), and stream water (23:1; as dissolved inorganic nitrogen:soluble reactive phosphorus). There were no clear temporal trends in the $\mathrm{N}: \mathrm{P}$ of excretion over time or in the $\mathrm{N}: \mathrm{P}$ of stream water over time.

The higher $\mathrm{N}: \mathrm{P}$ ratio of excretion compared to snail soft tissue, periphyton, and stream water suggested that phosphorus was limiting. This was also reflected in the higher molar $\mathrm{C}: \mathrm{P}$ of periphyton (492:1) compared to snail tissue (128:1). There were no significant correlations between the C:P of periphyton and $\mathrm{N}: \mathrm{P}$ of excretion $(R=-0.24$, $P=0.47)$ or reach-scaled phosphorus excretion rate $(R=0.47, P=0.17)$.

\section{Discussion}

A combination of biological and physical variables affected excretion by Elimia and its importance to nutrient cycling. Gross primary production and stream water temperature explained temporal variability in biomass-specific ammonium excretion rates, with higher gross primary production and warmer water temperatures resulting in increased excretion rates (Figure 8). The contribution of snail excretion to whole-stream nutrient cycling was greater when whole-stream nutrient demand and stream discharge were low (Figure 8). Last, very low phosphorus excretion rates and a high $\mathrm{N}: \mathrm{P}$ of excretion suggest that snails sequestered phosphorus and may exacerbate ecosystem-scale phosphorus limitation (Figure 8). Overall, Elimia appears to be both an important nutrient source (via ammonium excretion) and sink (via phosphorus sequestration) in Walker Branch. Temporal measurements of excretion and ecosystem metrics together provide a comprehensive understanding of the role of consumers in ecosystem nutrient cycling.

\section{Temporal Variation in Excretion Rates}

Biomass-specific ammonium excretion rates by Elimia varied over twofold over a period of 14 months in Walker Branch, coincident with seasonal changes in stream water temperature and gross primary production. Excretion rates were highest in spring before canopy closure when primary production was high. When the canopy 

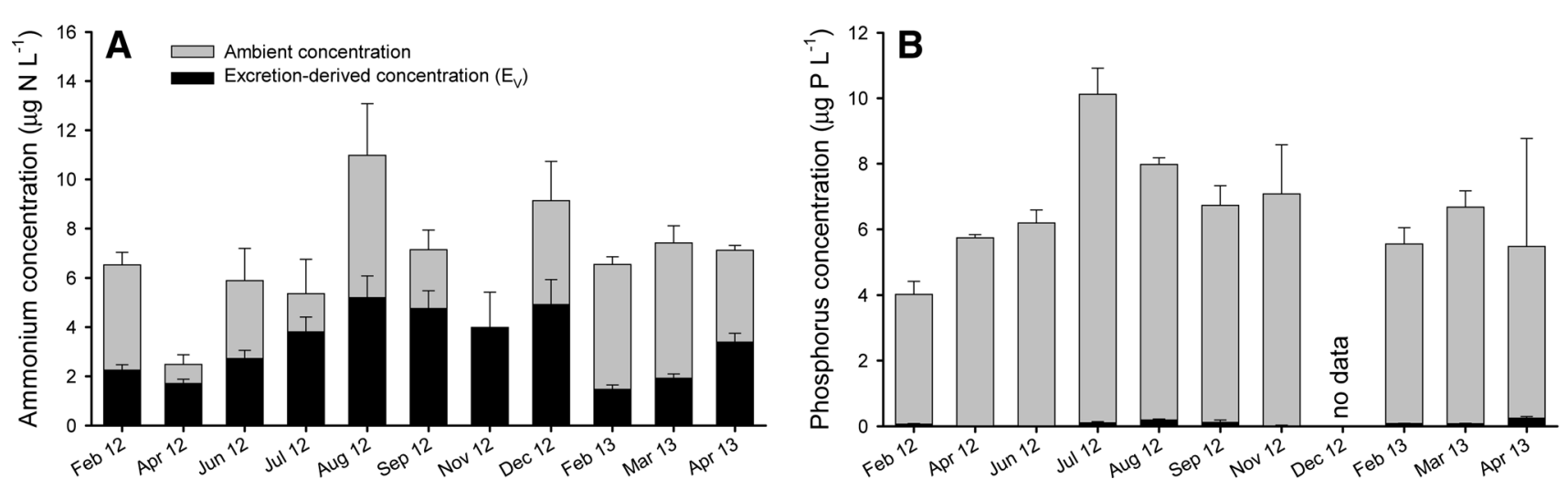

Figure 7. Concentrations of $\mathbf{A}$ ammonium and $\mathbf{B}$ total dissolved phosphorus in stream water (gray bars) from February 2012 to April 2013 overlaid with snail excretion-derived nutrient concentrations ( $\left.E_{\mathrm{V}}\right)$ (black bars). Phosphorus excretion was not measured in December 2012. Error bars represent propagated standard errors for excretion-derived nutrient concentrations. Error bars for background concentrations of ammonium and total dissolved phosphorus represent the standard error from samples collected during that month $(n=4)$.

closed, primary production was severely constrained by low light levels, and excretion rates on bedrock declined approximately $45 \%$ from midFebruary to mid-June 2012 (Figure 3). Food availability is an important factor controlling grazer excretion in streams where light and thus periphyton and algal growth are limiting. For instance, excretion rates of Tarebia granifer, an invasive aquatic snail, were higher in open-canopy habitats with greater food availability than in closed canopy habitats (Moslemi and others 2012). Food quantity is the most important factor controlling Elimia growth rates in Walker Branch (Hill and others 2010), which further supports the role of food availability driving snail metabolic processes such as excretion. Warmer temperature also can increase animal metabolism and thus excretion rates (Vanni 2002); however, the effect of temperature is not always straightforward (Gardner and others 1981), especially when more dominant controllers of excretion rates override the effect of temperature (Devine and Vanni 2002). The effect of temperature on Elimia excretion was evident in summer when food availability was low and fairly constant (Figure 3).

Although we found that food availability and temperature influenced excretion rates of ammonium (Figure 8), there were no clear temporal patterns in phosphorus excretion rates throughout the year. In general, phosphorus excretion rates were low and variable on a given sampling date. These low excretion rates may have been due to low phosphorus availability in the primary food source for Elimia. Periphyton N:P (38:1) was higher than that of snail tissue $(26: 1)$, indicating a relative scarcity of phosphorus for tissue production. When consuming phosphorus in relatively low supply, snails and other aquatic organisms can sequester it for growth, leading to relatively low phosphorus excretion rates (Cross and others 2003; Fink and Von Elert 2006; Rothlisberger and others 2008). In Walker Branch, phosphorus-poor periphyton may constrain phosphorus excretion by Elimia. When snails from Walker Branch were provided with phosphorus-rich periphyton from Beaver Creek, a nearby, high-nutrient stream, biomass-specific phosphorus excretion rates increased by more than tenfold (Walker Branch excretion = $0.4 \mu \mathrm{g} \mathrm{P} \mathrm{g}^{-1} \mathrm{AFDM} \mathrm{h}^{-1}$, Beaver Creek periphyton excretion $=17.7 \mu \mathrm{g} \mathrm{g} \mathrm{g}^{-1} \mathrm{AFDM} \mathrm{h}^{-1}$ (W.R. Hill, unpublished data); measured on the same date in November 2012).

Both the low phosphorus excretion rates and high variability on a given sampling date also may have precluded detection of a temporal pattern of excretion. Phosphorus concentrations in snail tubes during the excretion measurements were low and often similar to negative controls. Had the snail sampling area been increased to include more snails per tube, the variation in phosphorus excretion rates may have been lower, establishing greater opportunity for revealing a temporal pattern in excretion rates. However, we did not increase the number of snails per tube to avoid potential crowding artifacts. Although we failed to observe a temporal pattern to phosphorus excretion, our results do suggest that the low phosphorus excretion rates reflect the low phosphorus content of periphyton, which in turn reflects phosphorus limitation at the ecosystem scale. These results are consistent with several studies that show phosphorus is a limiting nutrient in Walker Branch 
(Elwood and others 1981; Rosemond and others 1993, 2000).

The few studies that have examined temporal variation in animal excretion rates found that food availability (Martin and others 2007) and temperature (Devine and Vanni 2002; Christian and others 2008) were dominant drivers, similar to our findings. Temporal variation in biomass-specific excretion rates is probably commonplace across animal species and ecosystems, and excretion measurements taken at one point in time are unlikely to represent average ambient rates. Not accounting for temporal variability may be especially problematic when scaling the importance of excretion to whole-stream nutrient cycling.

\section{Contribution of Excretion to Ecosystem Nutrient Cycling}

Elimia were significant contributors to whole-stream nitrogen cycling in Walker Branch, accounting for $26 \%$ of whole-stream ammonium demand, $66 \%$ of autotrophic nitrogen uptake, and $58 \%$ of stream water ammonium concentrations. These ecosystem metrics indicated that both biological (that is, nutrient demand) and physical (that is, hydrologic) factors controlled the importance of ammonium excretion to nitrogen cycling in Walker Branch (Figure 8). Area-specific excretion rates were similar across the four dates on which we simultaneously measured whole-stream uptake, but the contribution of ammonium excretion to whole-stream uptake was highest in September when nutrient demand was low. The contribution of snail excretion to stream water ammonium concentrations also was higher when stream discharge was lower in summer, and summer was when excreted ammonium could satisfy the highest proportion of autotrophic nitrogen uptake, due to shade constraints on autotrophic production. A variety of organism-specific (that is, excretion rate, biomass, community composition) and habitat-specific (that is, uptake rate, food availability, stream flow) variables were found to be important in determining the contribution of excretion to nutrient uptake in other stream ecosystems (for example, Hall and others 2003; McIntyre and others 2008; Benstead and others 2010), and thus, it seems likely that the importance of excretion to nutrient dynamics is both temporally variable and ecosystem specific.

The contribution of excretion to nutrient cycling also will likely depend on the mode of excretion of the organism being considered. Snails excrete nutrients through their shell aperture, which is necessarily close to the grazed substrate. Excreted nutrients are likely released within the substrate boundary layer $(\sim 1 \mathrm{~mm})$ and could quickly be taken up by biota on the grazed substrates (that is, periphyton on bedrock

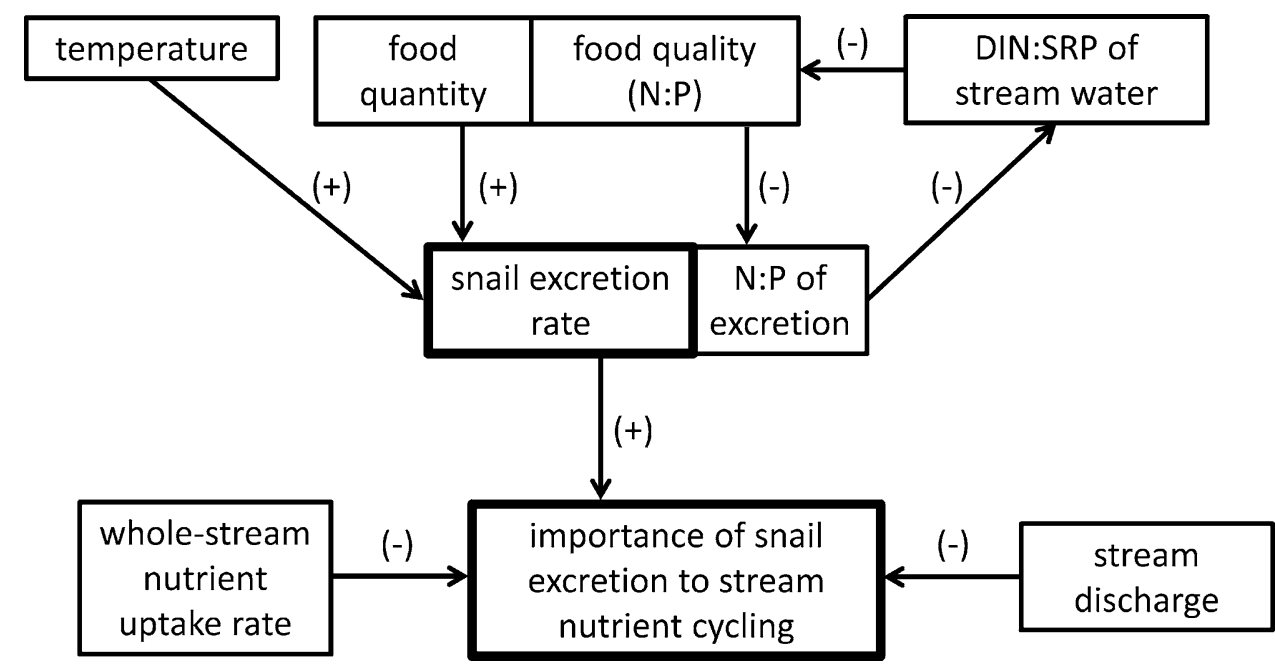

Figure 8. Conceptual diagram showing the factors affecting snail excretion rate and the importance of snail excretion to nutrient cycling in Walker Branch. Biomass-specific ammonium excretion rates increased with increasing temperature and food quantity (measured as gross primary production). The importance of excretion by Elimia to whole-stream nutrient cycling increased with higher area-specific ammonium excretion rates, lower whole-stream nutrient uptake rates, and lower stream discharge. Stoichiometric results suggest a positive feedback between DIN:SRP of stream water, N:P of periphyton (that is, food quality), and the $\mathrm{N}: \mathrm{P}$ of excretion, whereby the nutrient-limited status of Walker Branch resulted in poor quality food, which increased the N:P in excretion, further exacerbating ecosystem nutrient limitation. Bolded boxes represent the two foci of this study: temporal drivers of (1) snail excretion rates and (2) the importance of snail excretion to stream nutrient cycling. 
and cobble, biofilm on leaves), resulting in tight nutrient spiraling (Cuker 1983). In comparison, fish excrete nutrients higher into the water column, so there is a greater potential for these nutrients to be exported further downstream before being taken up. The comparison of area-specific excretion rates to whole-stream nutrient uptake rates assumes that excreted nutrients spiral downstream like an average nutrient molecule. However, if nutrients excreted by Elimia spiral more tightly than an average nutrient molecule in Walker Branch, the contribution of Elimia excretion to nutrient demand may be greater than estimated by reach-scale estimates of nutrient uptake. Understanding both organism attributes and stream ecosystem processes may help predict the contribution of consumer excretion to nutrient demand in a given ecosystem.

Phosphorus excretion by Elimia appears to be much less important to whole-stream nutrient cycling than nitrogen excretion. On average, phosphorus excretion represented only $1 \%$ of total dissolved phosphorus concentrations, and excretion turnover distances were an order of magnitude longer for phosphorus than for ammonium. Although we did not measure whole-stream phosphorus uptake using steady-state releases in this study, we can estimate the potential contribution of excreted phosphorus to whole-stream uptake with historical nutrient release data. Phosphorus uptake rates measured on six dates from 1978 to 1993 in Walker Branch ranged from 0.08 to $0.93 \mathrm{mg} \mathrm{P} \mathrm{m}^{-2} \mathrm{~h}^{-1}$ (Newbold and others 1983; Mulholland and others 1985a, 1997). Across these dates, the average reach-scaled Elimia phosphorus excretion rate $\left(0.006 \mathrm{mg} \mathrm{P} \mathrm{m}^{-2} \mathrm{~h}^{-1}\right)$ would have accounted for less than $1-7 \%$ of uptake. A similar analysis for ammonium using historical data (Mulholland and others 2000) indicated that the mean ammonium excretion rate $\left(0.18 \mathrm{mg} \mathrm{N} \mathrm{m}^{-2} \mathrm{~h}^{-1}\right)$ would have accounted for $8-13 \%$ of uptake.

Snail excretion probably exacerbates phosphorus limitation in Walker Branch, as the molar N:P ratio of excretion (89:1) was much greater than the molar N:P ratio of stream water (23:1). Low phosphorus excretion rates in fish and mayflies have been suggested to increase phosphorus limitation and alter consumer food quality over time (Hood and others 2005; Rothlisberger and others 2008), resulting in feedbacks between consumers and food quality (Sommer 1992; Andersen and others 2004). Because the N:P ratio of Elimia (26:1) is lower than that of periphyton (38:1), snails feeding on periphyton will sequester phosphorus relative to nitrogen in body tissue, and will have higher $\mathrm{N}: \mathrm{P}$ ratios in their excretions as a simple consequence of massbalance stoichiometry (for example, Elser and Urabe 1999; Sterner 1990) (Figure 8). Given that Elimia are long-lived species (several years) and are present at high densities in Walker Branch, they represent a large reservoir of slowly cycling phosphorus. Based on the mean reach-scaled biomass of Elimia measured during this study, these snails represent a phosphorus pool of $25.4 \mathrm{mg} \mathrm{P} \mathrm{m}^{-2}$, which was larger than the mean phosphorus pool in periphyton of $3.6 \mathrm{mg} \mathrm{P} \mathrm{m}^{-2}$ (estimated from periphyton abundance (in $\mathrm{g}$ AFDM $\mathrm{m}^{-2}$ ) in Mulholland and others (1985a, 2000) and converted to phosphorus based on an AFDM to P conversion for periphyton measured in our study). These estimates are higher, but show a similar pattern of higher $\mathrm{P}$ standing stocks in Elimia $\left(18.0 \mathrm{mg} \mathrm{P} \mathrm{m}^{-2}\right)$ compared to periphyton $\left(0.94 \mathrm{mg} \mathrm{P} \mathrm{m}^{-2}\right)$ reported by Newbold and others (1983). In Walker Branch, Elimia may affect nutrient cycling differently on short (that is, ammonium excretion) versus longer (that is, phosphorus sequestration) time scales.

Although our study focused on snail excretion as a contributor to whole-stream nutrient cycling, snails also can affect nutrient uptake via consumption of epilithon on bedrock/cobble and biofilm on leaves. Mulholland and others (1983, 1985b) found that Elimia decreased whole-stream phosphorus uptake by removing periphyton and biofilms while grazing. Snails, like other grazers, promote the downstream transport of nutrients both through excretion and through the reduction of microbial and periphyton biomass. Both consumption effects and excretion should be considered in estimating the complete effect of animals on whole-stream nutrient dynamics.

\section{Comparison to Other Studies}

The importance of Elimia to stream nitrogen and phosphorus cycling falls within estimates from studies encompassing a variety of organisms (fish, shrimp, snails, and invertebrate assemblages) and ecosystems (temperate, tropical) (Figure 9). Across 11 studies, areal excretion rates of nitrogen varied by three orders of magnitude, and the contribution of excreted nitrogen to whole-stream uptake ranged from less than $1 \%$ to greater than $100 \%$ (mean $33 \%)$. Areal ammonium excretion and wholestream uptake rates in Walker Branch were lower than in open-canopy, highly productive stream ecosystems with high consumer densities (for example, 32,000-109,800 invertebrates $\mathrm{m}^{-2}$ in Sycamore Creek, Arizona (Grimm 1988) and 483,000 snails $\mathrm{m}^{-2}$ in Polecat Creek, Wyoming (Hall and others 2003)). There was a significant, positive relationship between GPP and areal ammonium excretion $\left(R^{2}=0.97, P<0.0001, n=8\right)$ across the three studies that reported both rates (for example, 

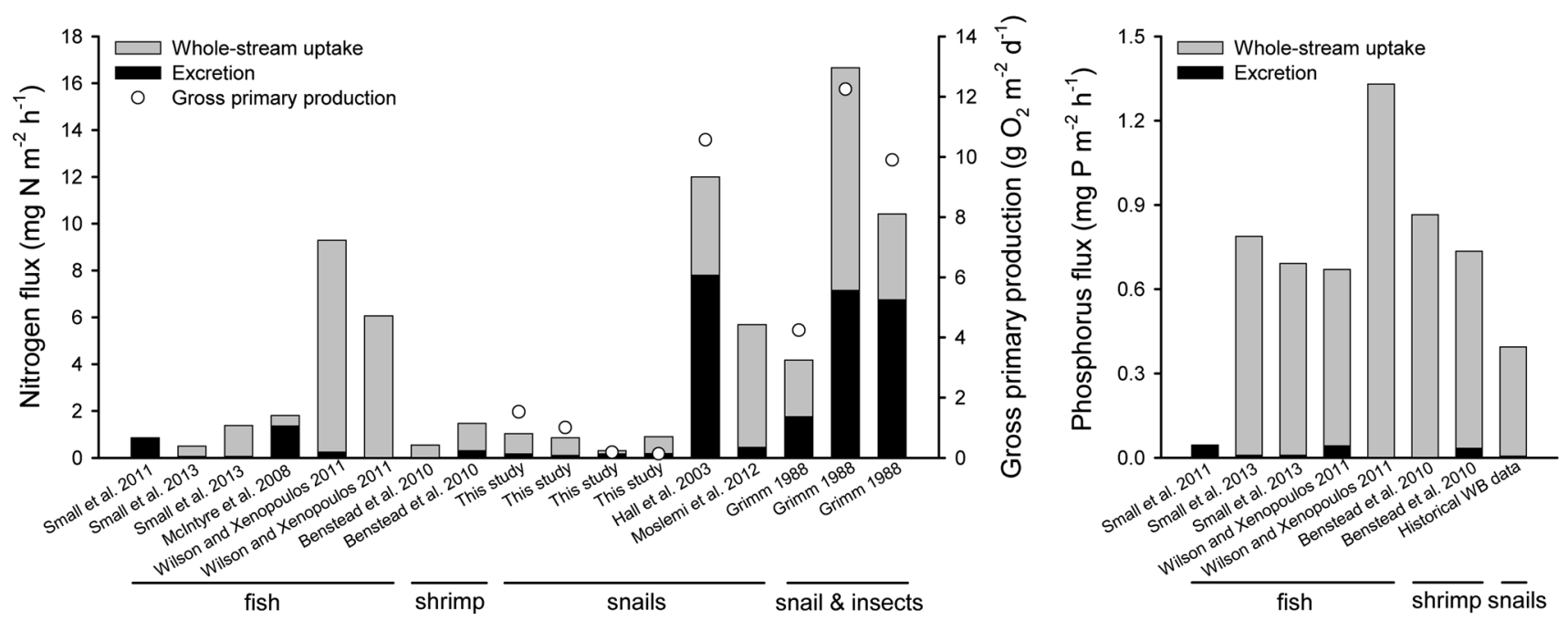

Figure 9. Synthesis of the contribution of area-specific animal excretion (black bars) to whole-stream nitrogen and phosphorus uptake (gray bars) in stream ecosystems. Gross primary production (white circles) was plotted when available. The historical Walker Branch (WB) phosphorus flux is the mean whole-stream phosphorus uptake rate (Newbold and others 1983; Mulholland and others 1985a, 1997) and the mean reach-scaled phosphorus excretion rate for Elimia measured during this study (data from Small and others 2013).

Grimm 1988; Hall and others 2003; this study), supporting the notion that food availability is one of the most important drivers of excretion rates across space and time. However, more studies that measure both excretion rates and GPP are needed to determine whether this relationship holds across other animal and ecosystem combinations. The contribution of excretion to phosphorus cycling across five studies was less than the contribution of ammonium (Figure 9), similar to our findings; however, the studies that measured very large ammonium fluxes did not simultaneously measure phosphorus fluxes.

\section{Potential Long-Term Dynamics in Walker Branch}

We examined temporal variation in excretion rates and effects on ecosystem nutrient cycling over 14 months, but the drivers of these processes (Figure 8) also change over longer time periods. In Walker Branch, air temperature has increased $0.047^{\circ} \mathrm{C}$ year $^{-1}$ (Lutz and others 2012) and changes in gross primary production associated with altered forest leaf phenology have been documented (Mulholland and others 2009), suggesting that biomassspecific excretion rates by Elimia may change over longer time scales than measured in this study. Interannual variation in hydrological conditions also may influence area-specific snail excretion rates. For example, the largest spate on record in Walker Branch reduced snail densities from approximately 2,000 individuals $\mathrm{m}^{-2}$ to 500 individuals $\mathrm{m}^{-2}$ in 2003, with recovery taking several years (W.R. Hill, unpublished data). Therefore, the drivers of biomassspecific and area-specific excretion rates by snails are changing over longer time scales in Walker Branch, suggesting that excretion rates are changing as well.

The relative contribution of snail excretion to whole-stream nutrient dynamics may also change over longer time periods. Over the past 20 years, stream runoff in Walker Branch has decreased by $34 \%$ (Lutz and others 2012), and it is during low-flow periods that snail excretion contributes most to stream water ammonium concentrations. Area-specific excretion rates also comprise a larger part of wholestream nutrient uptake rates when nutrient demand is low. It is not known whether whole-stream nutrient uptake rates have changed over time in Walker Branch; however, as stream metabolism and nutrient uptake are tightly coupled (Hoellein and others 2007), changes in the drivers of stream metabolism, such as temperature (Rasmussen and others 2011; YvonDurocher and others 2012) and forest phenology (Roberts and others 2007), will likely also affect wholestream nutrient uptake rates. Ultimately, quantifying the temporal drivers of consumer excretion and the factors that alter the importance of excretion to stream nutrient dynamics (Figure 8) will help determine how nutrient cycling in these ecosystems will change under future global change scenarios.

\section{Implications for Other Stream Ecosystems}

Although this study was conducted in one stream draining a temperate forested watershed, these 
findings are broadly applicable to other stream ecosystems. The drivers of biomass-specific excretion rates of Elimia, temperature and gross primary production, are likely to be significant drivers of excretion rates of other organisms and in other ecosystems as well (Devine and Vanni 2002; Martin and others 2007; Christian and others 2008). The seasonal variation in temperature and primary production in Walker Branch is also relatively small compared to other stream ecosystems. For instance, seasonal changes in stream water temperature are larger in tropical streams or streams lacking riparian cover (for example, agricultural streams) (Gasith and Resh 1999; Griffiths and others 2013) than in Walker Branch, which is a spring-fed stream with moderate temperature swings. Gross primary production is also more seasonally dynamic in open-canopy systems (Griffiths and others 2013). Therefore, biomass-specific excretion rates of aquatic consumers may be even more variable in other stream ecosystems.

\section{ACKNOWLEDGMENTS}

We are grateful to the late Pat Mulholland for his advice, mentoring, and friendship. We thank D. Brice, J. Childs, A. Fortner, and K. McCracken for technical assistance. Comments by R. McManamay, A. Stewart, and two anonymous reviewers greatly improved an earlier version of this manuscript. This research was part of the Long-term Walker Branch Watershed project and supported by the U.S. Department of Energy's Office of Science, Biological and Environmental Research. Oak Ridge National Laboratory is managed by UT-Battelle, LLC, for the U.S. Department of Energy under contract DE-AC05-00OR22725. N. Griffiths was partially supported by a postdoctoral fellowship through the ORNL Postdoctoral Research Associates Program administered by Oak Ridge Associated Universities.

\section{OPEN ACCESS}

This article is distributed under the terms of the Creative Commons Attribution License which permits any use, distribution, and reproduction in any medium, provided the original author(s) and the source are credited.

\section{REFERENCES}

Andersen T, Elser JJ, Hessen DO. 2004. Stoichiometry and population dynamics. Ecol Lett 7:884-900.

APHA. 2005. Standard methods for the examination of water and wastewater. 21st edn. Washington, DC: American Public Health Association.
Benstead JP, Cross WF, March JG, McDowell WH, Ramírez A, Covich AP. 2010. Biotic and abiotic controls on ecosystem significance of consumer excretion in two contrasting tropical streams. Freshw Biol 55:2047-61.

Brown KM. 2001. Mollusca: Gastropoda. In: Thorp JH, Covich AP, Eds. Ecology and classification of North American freshwater invertebrates. San Diego: Academic Press. p 297-329.

Brzezinski MA, Reed DC, Harrer S, Rassweiler A, Melack JM, Goodridge BM, Dugan JE. 2013. Multiple sources and forms of nitrogen sustain year-round kelp growth on the inner continental shelf of the Santa Barbara Channel. Oceanography 26:114-23.

Christian AD, Crump BG, Berg DJ. 2008. Nutrient release and ecological stoichiometry of freshwater mussels (Mollusca: Unionidae) in 2 small, regionally distinct streams. J N Am Benthol Soc 27:440-50.

Cross WF, Benstead JP, Rosemond AD, Wallace JB. 2003. Consumer-resource stoichiometry in detritus-based streams. Ecol Lett 5:721-32.

Cuker BE. 1983. Grazing and nutrient interactions in controlling the activity and composition of the epilithic algal community of an arctic lake. Limnol Oceanogr 28:133-41.

Davy SK, Trautman DA, Borowitzka MA, Hinde R. 2002. Ammonium excretion by a symbiotic sponge supplies the nitrogen requirements of its rhodophyte partner. J Exp Biol 2005:3505-11.

Devine JA, Vanni MJ. 2002. Spatial and seasonal variation in nutrient excretion by benthic invertebrates in a eutrophic reservoir. Freshw Biol 47:1107-21.

Elser JJ, Urabe J. 1999. The stoichiometry of consumer-driven nutrient recycling: theory, observations, and consequences. Ecology 80:735-51.

Elwood JW, Newbold JD, Trimble AF, Stark RW. 1981. The limiting role of phosphorus in a woodland stream ecosystem: effects of $\mathrm{P}$ enrichment on leaf decomposition and primary producers. Ecology 62:146-58.

Fink P, Von Elert E. 2006. Physiological responses to stoichiometric constraints: nutrient limitation and compensatory feeding in a freshwater snail. Oikos 115:484-94.

Gardner WS, Nalepa TF, Quigley MA, Malczyk JM. 1981. Release of phosphorus by certain benthic invertebrates. Can J Fish Aquat Sci 38:978-81.

Gasith A, Resh VH. 1999. Streams in Mediterranean climate regions: abiotic influences and biotic responses to predictable seasonal events. Annu Rev Ecol Syst 30:51-81.

Gettel GM, Giblin AE, Howarth RW. 2007. The effects of grazing by the snail, Lymnaea elodes, on benthic $\mathrm{N}_{2}$ fixation and primary production in oligotrophic, Arctic lakes. Limnol Oceanogr 52:2398-409.

Griffiths NA, Tank JL, Royer TV, Roley SS, Rosi-Marshall EJ, Whiles MR, Beaulieu JJ, Johnson LT. 2013. Agricultural land use alters the seasonality and magnitude of stream metabolism. Limnol Oceanogr 58:1513-29.

Grimm NB. 1988. Role of macroinvertebrates in nitrogen dynamics of a desert stream. Ecology 69:1884-93.

Hall RO, Beaulieu JJ. 2013. Estimating autotrophic respiration in streams using daily metabolism data. Freshw Sci 32:507-16.

Hall RO, Tank JL, Dybdahl MF. 2003. Exotic snails dominate nitrogen and carbon cycling in a highly productive stream. Front Ecol Environ 1:407-1 1.

Hawkins CP, Furnish JK. 1987. Are snails important competitors in stream ecosystems? Oikos 49:209-20. 
Hilderbrand GV, Hanley TA, Robbins CT, Schwartz CC. 1999. Role of brown bears (Ursus arctos) in the flow of marine nitrogen into a terrestrial ecosystem. Oecologia 122:546-50.

Hill WR, Ryon MG, Schilling EM. 1995. Light limitation in a stream ecosystem: responses by primary producers and consumers. Ecology 76:1297-309.

Hill WR, Mulholland PJ, Marzolf ER. 2001. Stream ecosystem responses to forest leaf emergence in spring. Ecology 82:230619.

Hill WR, Smith JG, Stewart AJ. 2010. Light, nutrients, and herbivore growth in oligotrophic streams. Ecology 91:518-27.

Hoellein TJ, Tank JL, Rosi-Marshall EJ, Entrekin SA, Lamberti GA. 2007. Controls on spatial and temporal variation of nutrient uptake in three Michigan headwater streams. Limnol Oceanogr 52:1964-77.

Hood JM, Vanni MG, Flecker AS. 2005. Nutrient recycling by two phosphorus-rich grazing catfish: the potential for phosphorus-limitation of fish growth. Oecologia 146:247-57.

James LAH, Xenopoulos MA, Wilson HF, Frost PC. 2007. Land use controls nutrient excretion by stream invertebrates along a gradient of agriculture. J N Am Benthol Soc 26:523-31.

Lutz BD, Mulholland PJ, Bernhardt ES. 2012. Long-term data reveal patterns and controls on stream water chemistry in a forested stream: Walker Branch, Tennessee. Ecol Monogr 82:367-87.

Martin S, Thouzeau G, Chauvard L, Jean F, Guérin L, Clavier J. 2007. Respiration, calcification, and excretion of the invasive slipper limpet, Crepidula fornicata L.: implications for carbon, carbonate, and nitrogen fluxes in affected areas. Limnol Oceanogr 51:1996-2007.

McIntyre PB, Jones LE, Flecker AS, Vanni MJ. 2007. Fish extinctions alter nutrient recycling in tropical freshwaters. Proc Natl Acad Sci USA 104:4461-6.

McIntyre PB, Flecker AS, Vanni MJ, Hood JM, Taylor BW, Thomas SA. 2008. Fish distributions and nutrient cycling in streams: can fish create biogeochemical hotspots? Ecology 89:2335-46.

McManamay RA, Webster JR, Valett HM, Dolloff CA. 2011. Does diet influence consumer nutrient cycling? Macroinvertebrate and fish excretion in streams. J N Am Benthol Soc 30:84-102.

McNaughton SJ, Banyikwa FF, McNaughton MM. 1997. Promotion of the cycling of diet-enhancing nutrients by African grazers. Science 278:1798-800.

Moslemi JM, Snider SB, MacNeill K, Gilliam JF, Flecker AS. 2012. Impacts of an invasive snail (Tarebia granifera) on nutrient cycling in tropical streams: the role of riparian deforestation in Trinidad, West Indies. PLoS ONE 7:e38806.

Mulholland PJ, Hill WR. 1997. Seasonal patterns in streamwater nutrient and dissolved organic carbon concentrations: separating catchment flow path and in-stream effects. Water Resour Res 33:1297-306.

Mulholland PJ, Rosemond AD. 1992. Periphyton response to longitudinal nutrient depletion in a woodland stream: evidence of upstream downstream linkage. J N Am Benthol Soc 11:405-19.

Mulholland PJ, Newbold JD, Elwood JW, Hom CL. 1983. The effect of grazing intensity on phosphorus spiralling in autotrophic streams. Oecologia 58:358-66.

Mulholland PJ, Newbold JD, Elwood JW, Ferren LA, Webster JR. 1985a. Phosphorus spiralling in a woodland stream: seasonal variations. Ecology 66:1012-23.
Mulholland PJ, Elwood JW, Newbold JD, Ferren LA. 1985b. Effect of a leaf-shredding invertebrate on organic matter dynamics and phosphorus spiralling in heterotrophic laboratory streams. Oecologia 66:199-206.

Mulholland PJ, Marzolf ER, Webster JR, Hart DR, Hendricks SP. 1997. Evidence that hyporheic zones increase heterotrophic metabolism and phosphorus uptake in forest streams. Limnol Oceanogr 42:443-51.

Mulholland PJ, Tank JL, Sanzone DM, Wollheim WM, Peterson BJ, Webster JR, Meyer JL. 2000. Nitrogen cycling in a forest stream determined by a ${ }^{15} \mathrm{~N}$ tracer addition. Ecol Monogr 70:471-93.

Mulholland PJ, Roberts BJ, Hill WR, Smith JG. 2009. Stream ecosystem responses to the 2007 spring freeze in the southeastern United States: unexpected effects of climate change. Glob Change Biol 15:1767-76.

Newbold JD, Elwood JW, O'Neill RV, Sheldon AL. 1983. Phosphorus dynamics in a woodland stream ecosystem: a study of nutrient spiralling. Ecology 64:1249-65.

Odum HT. 1956. Primary production in flowing waters. Limnol Oceanogr 1:102-17.

Rasmussen JJ, Baatrup-Pedersen A, Riis T, Friberg N. 2011. Stream ecosystem properties and processes along a temperature gradient. Aquat Ecol 45:231-42.

Richardson TD, Scheiring JF, Brown KM. 1988. Secondary production of two lotic snails (Pleuroceridae: Elimia). J N Am Benthol Soc 7:234-45.

Roberts BJ, Mulholland PJ. 2007. In-stream biotic control on nutrient biogeochemistry in a forested stream, West Fork of Walker Branch. J Geophys Res 112:G04002.

Roberts BJ, Mulholland PJ, Hill WR. 2007. Multiple scales of temporal variability in ecosystem metabolism rates: results from 2 years of continuous monitoring in a forested headwater stream. Ecosystems 10:588-606.

Rosemond AD, Mulholland PJ, Elwood JW. 1993. Top-down and bottom-up control of stream periphyton: effects of nutrients and herbivores. Ecology 74:1264-80.

Rosemond AD, Mulholland PJ, Brawley SH. 2000. Seasonally shifting limitation of stream periphyton: response of algal populations and assemblage biomass and productivity to variation in light, nutrients, and herbivores. Can J Fish Aquat Sci 57:66-75.

Rothlisberger JD, Baker MA, Frost PC. 2008. Effects of periphyton stoichiometry on mayfly excretion rates and nutrient ratios. J N Am Benthol Soc 27:497-508.

Seagle SW. 2003. Can ungulates foraging in a multiple-use landscape alter forest nitrogen budgets? Oikos 103:230-4.

Small GE, Pringle CM, Pyron M, Duff JH. 2011. Role of the fish Astyanax aeneus (Characidae) as a keystone nutrient recycler in low-nutrient Neotropical streams. Ecology 92:386-97.

Small GE, Torres PJ, Schweizer LM, Duff JH, Pringle CM. 2013. Importance of terrestrial arthropods as subsidies in lowland Neotropical rain forest stream ecosystems. Biotropica 45:80-7.

Sommer U. 1992. Phosphorus-limited Daphnia: intraspecific facilitation instead of competition. Limnol Oceanogr 37:96673.

Sterner RW. 1990. The ratio of nitrogen to phosphorus resupplied by herbivores: zooplankton and the algal competitive arena. Am Nat 136:209-29.

Stream Solute Workshop. 1990. Concepts and methods for assessing solute dynamics in stream ecosystems. J N Am Benthol Soc 9:95-119. 
Tank JL, Bernot MJ, Rosi-Marshall EJ. 2006. Nitrogen limitation and uptake. In: Hauer FR, Lamberti GA, Eds. Methods in stream ecology. 2nd edn. San Diego: Academic Press. p 213-38.

Uthicke S. 2001. Interactions between sediment-feeders and microalgae on coral reefs: grazing losses versus production enhancement. Mar Ecol Prog Ser 210:125-38.

Vanni MJ. 2002. Nutrient cycling by animals in freshwater ecosystems. Annu Rev Ecol Syst 33:341-70.

Vanni MJ, Flecker AS, Hood JM, Headworth J. 2002. Stoichiometry of nutrient recycling by vertebrates in a tropical stream: linking species identity and ecosystem processes. Ecol Lett 5:285-93.

Wilson HF, Xenopoulos MA. 2011. Nutrient recycling by fish in streams along a gradient of agricultural land use. Glob Change Biol 17:130-9.

Yvon-Durocher G, Caffrey JM, Cescatti A, Dossena M, del Giorgio P, Gasol JM, Montoya JM, Pumpanen J, Staehr PA, Trimmer M, Woodward G, Allen AP. 2012. Reconciling the temperature dependence of respiration across timescales and ecosystem types. Nature 487:472-6. 